\title{
Public Health in Different Political Systems of the State
}

\section{Authors' contribution:}

A) conception and design of the study

B) acquisition of data

C) analysis and interpretation of data

D) manuscript preparation

E) obtaining funding

\section{Andrzej Pawłucki}

University School of Physical Education in Wroctaw, Poland

KEYWORDS

\begin{abstract}
The goal of this paper is to explain the dependence between the political system of the state: collectivist, conservative, and liberal in a postmodern society, and public health-related practice. In the consideration of different systems of physical culture, including the system of health culture known as public health, Niklas Luhmann's theory of social systems has been used. The social system of health culture, hitherto known as the system of public health, is acknowledged as a variety of social systems of physical culture, whereas the health gymnasion is one of many possible centers of habilitation, recreation, and rehabilitation of the body. It is argued that an educating society can only persist successfully if the state does not lose control in the struggle against the ideologues of neoliberal forces hostile to the solidarity-based and welfare state.

physical culture, health-related fitness culture, public health, health education, pedagogy of health
\end{abstract}

\section{Introduction}

Public health is an abstract concept - a hypostatic construct. There is neither public health, nor the health of humankind. Health can be only assigned to an individual as substantial property, providing the individual with self-control. Health mysteriously "beams" from this substance, but the self-controlling individual can perfect it, prevent it hygienically from deterioration, or even protect it medically. An intelligent individual knows that life success can derive from the natural state of health (which explains making popular toasts to health), and that the realization of dreams can derive from perfected fitness and health. A healthier individual knows one can live longer than a healthy individual (although there are no toasts made to healthier health).

If man belonged only to himself, no one would be concerned with his state of health. A man needs society for his development. When a man enters social relationships, he recognizes society as a lasting relational entity ruled by some authority for the sake of the common good. Generally, an individual does not know - until he has seen it for himself - whether this relational world defies his respectful interpretation of personal development or not. Usually, individuals discover it does, but they never cease in their efforts to create a society of human persons.

It is not certain whether taking part in the common good produces creative manifestations of a personal life in individuals. Nevertheless, they must face health, fitness and wellness tests, and meet other 
standards of bodily perfectness. This is what is expected by the authorities of the community an individual belongs to. This biopower (M. Foucault) elevates health - a personal component of an individual - to the rank of public or even state good. This elevation is carried out in an almost uniform militaristic fashion. Once the authority recognizes that individual health relies on a social project, it initiates actions propagating the ideal of health and fitness (through health promotion and health education) and prevents public health from deterioration.

Indeed, public health is the art of controlling an individual's health. The mastery of this art, being the power over individuals' physicality, is like offering a guarantee of fulfillment of the highest ideals of human health condition.

\section{What is a social system of public health?}

Health is not disease, and public health is a social system that differs from the practice of disease treatment known as medicine and misidentified as the health service. The social system of public health has been designed to improve the vitality and state of health of healthy persons, while the social system of medical services has been developed to prevent somatic disease. There are, therefore, two distinct systems of physical culture of vitality: a system for refinement of health and vitality known as public health, and a system against disease and poor health aimed to recover health and vitality known as medical practice. The cultural and operational center of the public health system is the gymnasion; while the cultural center of medical practice is the hospital. The gymnasion is supervised by the paidotribe - a trainer of fitness, who teaches health refinement to the asketai, i.e., the trainee. In the same way, the doctor helps the patient regain lost health and vitality in the hospital. Moreover, both the healthy and the sick are aided by a plethora of specialized social agencies. Health services encourage the healthy to undertake the effort of physical selfrefinement and create the conditions for health "habilitation" in the space of health gymnasion. Medical services offer objective support to the sick and guide them through revitalization to the stage of independent rehabilitation of the body in the space of the hospital (from medical ward to rehabilitation ward). Both types of services, i.e. the health service for healthy persons and the medical service for sick persons, function in two different social systems.

One must not confuse the health service with the medical service, gymnasion with hospital, and the social system of health culture with the social system of medical culture. Only in one case can these realities be difficult to discern: the case of a rehabilitation ward in which hospitalized patients become transformed into gymnasion asketai, supervised by the ward head and his health service team often consisting of trainers of disabled athletes, who offer the practice of therapeutic exercises. In this case, it is hard to distinguish between a hospital ward and a sports gymnasion. Perhaps the two exist concurrently, such as in a quantum superposition, in which an elementary particle may exist in both states simultaneously.

In my opinion, the peculiar nature of a hospital gymnasion is manifested in its superposition, i.e. by concurrent social relations between the medical and physical rehabilitator and the patient becoming a selfdeveloping trainee exercising his inner and outer body at the same time. There is a common confusion between two social orders: pro-health and medical, and thus there is a pressing need to disambiguate the concept of social system of health culture. Usually, whenever "public health" is mentioned it is associated with disease, medical services, doctors, and hospitals. This is colloquial and wrong. We are wrong when we refer to the health service only in the context of the sick aided by the hospital service - but not the health service - in disease treatment and convalescence. The health service is not in the hospital, and the medical service is not in the gymnasion. The medical service keeps persons in a hospital ward alive. It recognizes the weak and sick as patients. The health service supports the lively and the healthy, who - in gymnasion conditions - refine their bodies. Despite obvious differences between the two services, students of public health tend to think of health only in medical terms, i.e. in the context of disease, while students of physical education do not perceive physical culture as being saturated with health content. Furthermore, students of medicine usually regard the issues of public health in an epidemiological perspective. 


\section{Theoretical background}

In the consideration of different systems of physical culture, including the system of health culture known as public health, Niklas Luhmann's theory of social systems may be used. According to Luhmann, modern societies do not involve participation of particular individuals (persons), but rather particular social statuses or roles associated with these statuses. A social system, e.g. a hospital, is a set of interrelated statuses - such as the head of a ward, doctors, nurses, physical rehabilitation therapists, radiologic technologists and patients - in which everyone performs specific complementary roles assigned to them (Sztompka, 2002, p. 30). Thanks to its "subjectless" premises, the theory of social systems permits a macro-analysis of cultural reality disclosing inter-system and causal relationships.

N. Luhmann, who utilized Talcott Parsons's theory of social systems, claims that modern societies organize themselves into multiple communication systems in order to undertake and accomplish their tasks. Each system manifests its specificity with a binary code. For instance, the function of the system of sport is communicative operationalization of bodily fitness of a person according to the binary code of fit/unfit (Stichweh, 1990, p. 387). Considering the social system of physical culture in sport, there is a valid question whether the fit/unfit code is appropriate. Encoding the social system of sport becomes difficult, as it must account for the nearly metaphysical distinction between ludic sport - as a system rooted in the culture of physical existence - and Olympic sport rooted in the culture of symbols. The two sport systems are only seemingly similar. The fit/unfit binary code becomes useless when confronted with the full membership of Olympic parathletes in the sport family.

In his critical commentary of Luhmann's theory, Andrzej Nowak stipulates that binary codes are crucial for understanding modern societies (Nowak, 2011, p. 87). By aiming at reducing complexity, social systems use binary codes which allow the selection of indirect environmental stimuli. These codes are profit/loss in economy, true/false in science, and legal/illegal in law, etc. According to Nowak, the systems handle autopoiesis effectively and strictly comply with the "clarity" of their binary codes. If, then, social systems of communication maintain the transparency of their binary codes so well, the system of the medical service, with the hospital as its operational center, should have become independent of the "influences" of a seemingly similar, but in fact entirely different, code of the health service. This overlap of codes has been most likely due to the abuse of the term "health" to describe a situation negatively affecting a patient with a "habitus of sickness", metaphysically referred to as habitus entitativus. We will start recognizing the social system of the non-medical (health) service better, if we acknowledge that:

a) Its only possible operational center is not the hospital but the gymnasion, and its chief operator is not the doctor but the paidotribes, who establishes a relationship not with the patient, but with the asketai;

b) The positive pole of its binary code is a cultural form affirming vitality and health with bodily exercises, and the negative pole is a cultural form negating the pro-health sense of bodily exercises.

Thus, the system of public health seems to permit an epidemiological communicative approach, expressed by way of a binary code: threat of disease vs. health assurance. It is undeniable, however, that the dynamic pro-health cultural movement initiated in the 1970s has facilitated pro-health attitudes in many modern societies, created the cultural figure of pro-health asketai, assigned the role of health coach to the gymnastic instructor, and made the health gymnasion its operational center. It is indisputable that the social system of health culture validates the gymnasion as the operational center in which the health ideal can be attained. The social system of health culture, hitherto known as the system of public health, is acknowledged as a variety of social systems of physical culture, whereas the health gymnasion is one of many possible centers of habilitation, recreation, and rehabilitation of the body.

\section{Gymnasion and hospital: two transitory places}

The gymnasion is, in general, the place of bodily creations. Its participants, i.e. asketai, assume that their acting activities require appropriate bodily competences to attain the health ideal. An actor in a social 
system must undertake another task preceding the execution of his role: he must find or create a place (as a personal gymnasion), in which he will perform pro-health exercise of the body. For every actor, the gymnasion is a place of transition to destined social systems. No one attends the gymnasion or the hospital to remain there forever. Both are transitory places. In their transience they are similar, being two centers of social systems of bodily culture. The gymnasion is a transitory place for cultivation of the body in good health through habilitation, recreation and rehabilitation of bodily afflictions. The hospital is a transitory place for recovery of the sick body through medical reanimation, convalescence, and rehabilitation of bodily afflictions. The transitivity of the hospital and the gymnasion is explained by the indispensability of renewal of bodily aspects of persons participating in social systems placed higher than the system of physical culture. While the fitness asketai leaves the gymnasion to perform assigned social tasks, the patient leaves the hospital to resume his suspended social tasks. In the social culture of the gymnasion, the model role of the fitness asketai is ultimately non-social, i.e. a trainee must perform the task of bodily creation by himself, in accordance with its model and assigned value. Depending on the value added to the body, the gymnasion offers the asketai important social models. The health-model gymnasions, despite their universal purpose, are one of many gymnasion types. With regard to the type of values assigned to the body, we can distinguish the following model gymnasions:

1. Gymnasions of existential models of physical culture for the realization of:

a) The biotic value of the body, by performing the role of an apologist of life and vitality in every social system;

b) The vital value of the body, by performing the roles of pro-health asketai and patient undergoing treatment through movement as well as the associated role of rehabilitator;

c) The utilitarian value of the body, by performing the role of ludic athlete and the associated role of trainer, the role of recreation asketai and associated role of animator; the role of military gymnastics asketai and the associated role of instructor of utilitarian exercises; the roles of firefighter and law enforcer, and the associated role of their trainer.

2. Gymnasions of symbolic models of physical culture for the realization of:

a) The agonistic value of the body, by performing the role of Olympian and the associated role of trainer;

b) The perfectionist value of the body, by performing the roles of circus artist, magician, illusionist, conjurer, equilibrist, strongman, animal tamer, and the associated role of trainer;

c) The aesthetic-artistic value of the body, by performing the roles of artist, dancer, ballet master, mime, stage actor, and the associated roles of trainer as well as dance, ballet, and drama instructor;

d) The mystical value of the body, by performing the role of believer and the associated role of priest in the practices of ascesis, penitential martyrizing of the body, celibacy, and ritual ablutions.

3. Gymnasions of social models of physical culture for the realization of:

a) The customary-aesthetic value of the body in practices of "dressing", "building" the body, smoothing body movements, gestures, and enunciation related to each performed social role;

b) The hedonistic-aesthetic value of the body in practices of emphasizing or diminishing sexual attractiveness of the body related to the performed roles of hedonist or ascetic;

c) The betrothing value of the body in practices of maintaining bodily purity as well as vital and reproductive fitness related to the performed roles of fiancé, spouse, or parent.

In fact, there is a definite number of gymnasions in the logical sense. Each gymnasion legitimizes the social system of physical culture in its own way. It cannot be identified with the entire system of participation in culture, but it is necessary for this participation. This is why participants in cultural systems would not be able to perform their tasks properly, had they not been participants of physical culture. Certainly, no one can fulfill his or her roles ideally, if one does not participate in the social system of physical culture as an asketai of the health gymnasion. However, as it will be disclosed later, participation in 
the health gymnasion depends on whether the state pursues public health policies, and whether the state embraces bodily values of the health of individuals as the common good.

\section{What is the common good?}

In their care about human dignity - whose value is always higher than the value of society, regardless of the hierarchy adopted by the authority - ethicists and pedagogues emphasize that the raison d'etre of every human being is the realization of "aspirations to knowledge, love and self-determination" (Krąpiec, 2005, p. 341). When an individual actively pursues these values that constitute his personal good, he makes it clear to himself that he is the aim and the meaning of his own existence. Certainly, one individual can unlock his personal potential providing he enters, through an act, a relationship with another individual. And each individual in such a social relationship may covet the same good as anyone else. Each individual opens the chapters of humanistic self-development (in the book of social life) through acts of affirmation of another man, regardless of any cultural links. Each link is good because in each cultural undertaking, persons who are equal in their humanity meet each other. A person knows then that the subiectum of the relationship is far more important than the obiectum of the link and than the authority itself. When both subjects in the relationship recognize the coveted good in the same way, i.e. discover that the acting subject is more important than the cultural object, they mentally construct in the axio-sphere the same affinity for the coveted good. They leave a permanent, although invisible, trace of their existence: a social culture of a person. Thanks to this reflexive thought, the good we all desire individually may become - as the aim of an individual's action - the common good of all participants of cultural life.

However, when an individual is not acknowledged as a person by the other subject of a social relationship, in particular, by the state power; or when an individual's personal good is replaced with some objectified, material, non-personal good, then it ceases to be the highest form of being in its world. According to Krąpiec: "There is no more complete autonomous form of being than a person". Thus, when the state power ideologically places its coveted good over the good of a person, it makes a human person a plain unit of the system. In its dependence on the authority a human being deprived of personal self-control becomes objectified, constrained, and "uniformed" (Krąpiec, 2005, p. 341). But he or she can also become liberated in order to pursue individualistic self-determination and independence. In a collectivist and authoritarian state system, an individual is deprived of the right to self-determination in personal dignity. He or she must become a part of a collectivist whole and abandon any aspirations of the ideal of person and community. In a liberal and individualistic state system, an individual, who is encouraged to make totally free choices, deprives oneself of personal dignity by "becoming trapped by consumerism, disorderly sex life and violence and ending in loneliness, walking astray in the culture of death"1.

The common good is thus, by analogy, the same good an individual covets to perfect his personal humanity when he gets into a social relationship with any other individual in the spirit of mutual respect, kindness, friendship, and love. Any other common good that is not personal good is by logic a false good. There is no other ontological entity that can be made supreme by the state power than an intelligent and autonomous human person. It is a being for itself and by itself. If this elevation to supremacy takes place in political praxis, then the personification of a social construct becomes, as Krąpiec demonstrates, "a totalitarian entity which deprives the human personality of its inalienable rights" (Krąpiec, 2005, p. 341). The imposed good which expropriates the personal existence of an individual reduces the individual's physicality, including physical health, to an object. On the other hand, the public practices of the state authority in the areas of physicality, vitality, and state of health of individuals are rationalized by the good which is ideologically justified but not by the common good which rationalizes the good of a person. The authority maintains the state of health through a network of policies of physical fitness improvement, not

\footnotetext{
${ }^{1}$ W trosce o czlowieka i dobro wspólne (For Man and the Common Good) Council of Social Affairs, Polish Episcopal Conference, Warszawa 2012, Biblos, p. 35.
} 
directed at an individual but at itself, by way of nationalization of all collectively and physically integrated individuals. It tries to attain the absolute good at the expense of the good of a person and a community. Public health as a state power's practice becomes an ideology (following the only accepted good of a nonpersonal being), while individuals, who are forced into submission, are deprived of their dignity - they become impersonal.

\section{The state power and public health}

A certain correlation can be noted. An individual's health lends authority to biopower in the process of attaining the common good, while biopower - undoubtedly fully aware of the significance of health matters - endorses individuals in all their activities aimed at health and fitness maintenance. Thus assured individuals, through education or promotion, who are the reasons for their own physical good, can convey health perfection in their existence into perfection in social action. An intelligent biopower knows what it does. By making one's health public, it achieves two objectives at the same time: adds cultural success to the society in reaching its ideals, and lets individuals take part in their personal self-determination. When the two goods: social and personal, come together, i.e. when the axio-normative social order allows individuals to undertake actions that affirm their personal good, then the ethicist, the pedagogue, the cultural philosopher, or the social philosopher - on their grounds of humanist social ontology - can confirm that social life has achieved the community ideal. They can proclaim that the social organization maintained by the state authority and biopower is for people, as "the highest good is the highest possible development of an individual" (Znaniecki, 1973, p. 23, vol. II). Therefore, when a legitimate state power affirms personal good as the highest good, then both public health and biopower become parts of the humanistic ideal.

The ideal of public health is still the one state power policy in the service of the community for the personal good of individuals. The history of public health, however, shows that any social system "incorporating" political ideals tends to degrade personal aspirations in liberalist postulates, or even force individuals to participate in degrading actions in utopian, authoritarian, impersonal systems. There have always been voracious groups of ideological usurpers, religious sectarians, self-proclaimed leaders, or invisible leaders of postcolonial power that prowl after the soul, body, health, and life of their individual and collective victims.

Considering the idealized European state systems, one can distinguish three models of public health adopted by the state biopower:

A) Collectivist - by authoritarian states,

B) Conservative by welfare states,

C) Neoliberal - by non-ideological pragmatic states.

\section{A) Public health in a collectivist state}

No one should take lessons in public health, or more precisely nationalized health, from a collectivist state power. It is an inhumane power that controls all spheres of individuals: spiritual, volitional, intellectual, emotional, substantial, physical, sensual, corporeal, and health-related. There is no feature of individuals that remains outside the control of the authoritarian state power. As the spheres of an individual are indeed many, the authoritarian state power delegates its duties to its subordinate apparatuses of control and coercion. A biopower apparatus controls the participation of individuals in practices of physical fitness according to an imposed specific pattern: most often physical-utilitarian (in the context of professional and military duties), geneonomic (in the context of "blood purity"), and health (in the context of social roles in the public sphere).

In Polish society, once governed in an authoritarian way by the communists - biopower made public, or more precisely nationalized, the physical health of individuals in the area of medical services. In a 
particular way, it favored the utilitarian collectivist (workmen's and military) bodies. It also nationalized the agonistic model of physicality by centrally controlling the procedures of sport training.

History shows that biopower in authoritarian societies always expresses its intense interest in health and utilitarian fitness of collectivist individuals, which may be indicative of its seemingly humanistic disposition. In fact, biopower which represents a single-party state must maintain strict control over the minds and bodies of individuals within a certain revolutionary project whose final outcome - expressed in the form of illusion of an absolute utopia of happiness - depends on the physical strength of its champions. The cynical anti-humanism of biopower is manifested in a strategy of unconditional sacrifice of health and life anytime the country requires it from individuals. Public health in an authoritarian state system takes on the mystifying appearance of humanism. A healthy individual in a collectivist state is not supposed to be involved in activities related to his personal dignity. Love is not where healthy collectivists find their true vocation. According to the planned, pragmatic health policies, individuals in a collectivist state train their fitness to a supreme level in order to prove their steadfastness in revolutionary acts. Young students build up physical strength and develop their utilitarian skills in youth organizations. Adults are drafted into civil and military service. Individuals advance from one organization to another, and enlist in more and more elaborate organizations. Individuals are not bothered with their own bodies, health or even lives. Biopower does it all for them. An individual in a collectivist state does not engage in promotional activities aimed at development of personal fitness, as the anthropological premise is that a good collectivist must be an obedient executor of assigned tasks. Subjectivity is not a collectivist feature, as individuals in a collectivist state are not allowed to perform activities in the domain of their personal dignity. A collectivist is not a person. Even if they were to find their vocation to be part of their personal dignity, i.e. to show love to another individual in a marriage or family, their right of self-determination would be denied ${ }^{2}$. Respective ideological indoctrination services of state power are in charge of "personality incapacitation" of individuals. If necessary they can even isolate oppositionists by declaring them insane. A party agency takes care of the health and fitness of collectivist individuals. And although all individuals fit for duty grow healthier and stronger, they are not allowed to cherish their personal dignity on the grounds of their perfectly trained physicality. The public health policy or state health policy in authoritarian states is inhumane. It carries no collective experience to a conservative state power, let alone to a liberal powerless state.

\section{B) Public health in a conservative state}

The history of state organizations shows that a state model which is closest to the humanistic ideal of personal dignity in public health understood as a social policy of the biopower, is the welfare and solidaritybased state. The furthest from the ideal is the liberal, non-ideological, pragmatic state which produces liberalistic and individualistic re(actions) in society. Equally far from the ideal remains authoritarian (antidemocratic) state power. The idea of increased control over individuals' health and fitness by biopower (as an institution of oppression and coercion) in authoritarian societies is the impersonal good of the state system. In the name of this good, in case of any "historic" necessity, individuals will have to sacrifice not only their perfected health but also their own lives.

In general, apart from ideological differences between state systems, public health policy gains a reason for existence only in such axiological conditions that legitimize the common good as the main principle uniting individuals for the same cultural ideal. Societies that remove the common good from the axio-sphere are not justified to seek health perfection in the public sphere. When there is no ideal uniting all into one community, there is no reason for making health public a common good. This negative correlation is particularly visible in societies ruled by states affirming the individualistic ethos of neo-liberal practices.

\footnotetext{
${ }^{2}$ In the famous screen adaptation of Doctor Zhivago by Boris Pasternak, an adult couple with a child become "disillusioned." With revolutionary earnestness they renounce their personal dignity and sacrifice their love to each other for the "motherland."
} 
A good state establishes good practices of the wellbeing of healthy individuals according to the following pattern: a welfare state creates institutions of public health, which then disseminate the ideal of public health. In this causal sequence, health-empowered persons actively maintain their fitness and attain the state of health ease and wellbeing. Such persons are prepared to carry out tasks in the community as their vocations and challenges. In an ambitious life, in which a man "revealed through love" (Tischner, 2000) is the sanctity, a person needs perfected fitness. That is why in the lives of individuals, health education is necessary for their self-fulfillment in the community of caritas. Health education shows that the value of health serves higher values, i.e. that good public health and life-as-life practices are inferior to values constituting a person in his or her existence and activities.

The ideal of health-oriented personalism is "designed" as a utopia of conservative society with its aspirations towards a welfare state. Although true welfare providers do not exist (according to neo-liberals the welfare state has overexploited its potential of public good), we are not the only ones who reproach the free marketers of supranational capital (for example, John Rawls, who is far from being a conservative) for abandoning the ideals of social justice, moral rightness, and recognition of the common good by the state. Even if this type of narration:

" [...] savors of socialism, it is a type of liberal thinking centered on a concept of life and culture, an ideal of interpersonal relations, and not on free market economy" (Szacki, 2008, p. IX).

This ideal implicitly assumes the personal development of individuals in their creativity and love. It is the common good uniting all participants in social life. What is good for an individual (and individuals only want all that constitutes their personal selves) is good for all participants in social life, as all of them require the same good for themselves. This way, the personal good as an ideal, thanks to relations with others, can be recognized as the common good of society. Therefore, the health-related good of an individual as one's ontological basis should be, consequently, recognized as the public good that determines, like any other physical or material goods, the achievement of the social ideal of the person in the community and the community for the person.

The understanding of the above relationship leads to the control of state power over public health as the common good. Through various health and fitness policies, the state enables the exploration of the real possibility of submission to the common good through development of personal potential (Szacki, 2008, p. IX).

It was the Western states of good capitalism of the 1980s - states that were truly welfare-oriented, subsidiary and solidarity-based - that started the process of universal health culturation as different from the traditional health medicalization. Following a number of world congresses on health promotion in the public sphere, a network of health promoting schools was established, and extracurricular activities were undertaken promoting models of the improvement of health and fitness. It should be added that Poland, which at that time was departing socialist totalitarianism for a better vision of democratic social life, did not adopt any Western European model of good welfare or subsidiary state in the public sphere. In the nonmedical sphere of public health in Poland, no efforts were made to subscribe to the cultural health promotion movement started in Canada and legally founded in "The Ottawa Charter for Heath Promotion" - a document recognizing social inequalities as the cause of health inequalities and regarding public health as a modus of ordered and worthy existence. The Polish National Health Programme was fiction. Poland never joined the European Network of Health-Promoting Schools, and none of the "perennial" postulates of national health pedagogy has ever been satisfied, in particular, improvement of the health of public school students. None of the 3,000 planned health promoting schools has been established, and despite demands of public health activists, the educational reform has been delayed. The long anticipated public health care bill has never been consulted by Polish society. At present, the state power of free market democracy evades its responsibility for the common good of ill persons. In the public medical practice (known as the national "health service"), ill persons, despite constitutional guarantees, must liberalize themselves in order to help 
themselves. When biopower delegates its welfare obligations to the sick, who are to purchase their medical insurance in private institutions, the non-ideological state apparatus (in the personalistic sense) also takes a liberal approach to the health of the able-bodied. Moreover, a non-ideological state does not even initiate a discussion on public health. The monetary pragmatism of the free market state power assumes singular relations with individuals perceived as "human capital." And if individuals are to hold their own capital, all ontological properties are then put on the free market: disease, health, and even life (staying young, living longer or eternally). Whoever cannot afford them must stick to their own health poverty and shorter lifespan.

\section{C) Public health in a liberal-individualistic state}

In a pragmatic non-ideal society, in which public health is not part of the common good, since an individual as a person is not the highest good for the state power, health maintenance becomes an individual activity. Each good is different, each individual desires something different. Depending on an individual's concept of coveted good, a personal, clearly non-public, health and fitness practice is justified by this good. An individual who "individualizes" his or her life can:

a) Develop physical fitness and succumb to healthism;

b) Improve health and fitness to experience hedonistic sensations. This goes for individuals who value their independence (through selfish calculation of happiness: everyone plays for himself) and succumb to sad nihilism, happy hedonism, new sexualism, or cosmic energetism;

c) Engage healthily in acts of celebrity vanity or, at best, in a professional career of an individual.

Health and fitness are of main concern to those individuals for whom the reason for existence is their career and fame. Their attitude to life is also "free", as the freedom of an individual is the ultimate objective. Postmodern individualists engage easily in discourses on euthanasia, abortion, and in vitro fertilization, as for them life is not problematic, if it follows their patterns of youth, health, sensual beauty, and sexual fitness.

An individual in a postmodern society justifies his health maintenance using hedonistic and utilitarian reasons. The state power does not recommend or impose anything on individuals, as in the society of "free men", every one maintains his or her health and fitness according to their "privatized" good.

In non-ideal pragmatic societies, deprived of the common good, the public value of health is not perceived as the coveted good. Poland is an inglorious case of a non-ideal pragmatic state in which after the removal of the biopower of the authoritarian state, no reformed state apparatus in the spirit of good welfare capitalism has ever been established. The ministerial biopower apparatus in charge of universal fitness of all citizens was liquidated, and organizations of propagation of physical culture that had legitimized the authority of the totalitarian state were dissolved. Despite the convenient historic opportunity, public health policies according to welfare state patterns were forsaken.

A self-limiting democratic state that follows a strategy of market neo-liberalization evades responsibility for the ill, the poor, the homeless, the unemployed, and the excluded. It coldly calculates public finances and arrives at the decision not to make health or disease public. Not only does it refrain from its budgetary obligations in the area of health promotion and education (not to mention emergency epidemiological services) under the pretense of a difficult legislation process of the public health bill, but it also attempts to liberalize hospice care for the terminally ill (Legutko, 2012). The ill are directly charged for personal medical services in public health institutions, despite the constitutional guarantees of public medical insurance. Finally, patients become individual customers of medical services, who are self-insured in private healthcare funds (Straus \& Straus, 2009, p. 304) 3 $^{3}$ The neo-liberal, non-ideal state in its heartless pragmatics of liberalization of citizens (in all contexts of their constitutional claims), confined in the newspeak to

\footnotetext{
${ }^{3}$ Like in the American model of Health Maintenance Organization in which affluent customers can insure against the risk of incurring medical expenses in six private healthcare providers. Pathologies connected with the system are discussed by E. W. Straus and A. Straus.
} 
"human capital", lacks the knowledge of good capitalist culture (it is also an anti-conservative state unfriendly to family and its ethos of natural rights, and hostile to the national-Christian tradition). How was this state supposed to learn good culture when right after abandoning all collectivist legacy, it eagerly adopted neo-liberal and turbo-capitalist strategies in the economic sphere? In fact, the Polish state has never experienced the humanism of welfare and solidarity-based free-market democracy. Although there has been much talk, the acts have never followed.

By accepting the premise that the ethos of social policy of EU states depends on the internalization of humanistic traditions of capitalist culture (Szubert-Zarzeczny, 2001, pp. 40-51), one can suppose that in a pragmatic non-ideal state deprived of the common good, the public value of health must not be the subject of debate, and the question of life as life is always regarded, in relativist and permissive terms, in opposition to natural law ethics. The consideration of health and bodily purity as the public good is impossible in a liberal-individualistic state dominated by consumerist and hedonistic mentality. No legal regulation such as a public health bill will effectively influence the liberal anti-health practices. Even in the once most health-oriented society of adult Swedes, making health the public common good is impossible at present. The individualist excesses of younger Swedes adhering to the hedonistic ideology make their participation in the health movement affirmed as a common value. In addition, the existential nihilism of those disappointed with their experience of liberty, craving to seek the sense of power on their own and disillusioned with the impossibility of fulfillment of ideals, excludes them from participation in the common good of health.

\section{An individual's health in a postmodern society}

In general, the less impact the state exerts on the public sphere, the more affiliation of individuals in social categories can be noted. Membership of these categories often remains in opposition to the values of life, health, and personal dignity. In "stateless" (libertarian) societies where ideological control over culture disappears - which takes place in pragmatic non-ideal democracies or individualistic, post-modern, and neoliberal states - new, self-proclaimed ideologues take their turns in representing various groups of free market interests. The only function of the state which does not cease is the watchdog function in the area of public security and defense of physical culture. Both the policeman and the soldier must become actively involved as ordered in the development of their own physicality to contribute their physical skills to the glorious tasks connected with their social roles.

I merely expose some selected acts of anti-health vandalism of postmodern ideologues, which the nonideal state power in Poland is unable to tackle in the public discourse. Polish state agencies, especially the "dormant" or rather "research-obsessed" Polish National Institute of Public Health, is notoriously absent in this discourse. If it were truly a "national institute," regardless of its statutory assignments, a pedagogue demanding good practice in national public health would not have to chastise the said Institute. In the same way, the pedagogue must constantly remind the Polish president and prime minister of their responsibility for the National Health Programme and admonish them for their lack of participation therein.

Biopower (if it is still there) remains silent, and the ideologue of postmodernity encourages individualism, de-socialization, and selfish singlehood. It promises happiness on one's own, but keeps the individualist unaware that the hedonistic occupation of the body is at the expense of the latter's health through "drowning" in one's natural being (like drowning one's sorrows in drink). The life of man in his natural structure of being is theoretically possible, although it is a life with no "added" value. The hedonist becomes similar to the so-called non-problematic man. Jan Patočka in his Heretical Essays writes that a natural man or non-problematic man, who has not yet developed his history intellectually, attaches life to himself. He exists by sacrificing life to itself, only to fulfill his natural needs. In other words, a nonproblematic man lives for physical life (Patočka, 1998, p. 23).

The health pedagogue, who now again assumes the role of bio-pedagogue, reminds us that it is impossible for a man in his natural being to become a person. The cultural sphere is not possible when a man 
creates an axiological context only for the singular value of the body. The health pedagogue shows that the man of axiological absurdity does not have to be sought in the philosophical imagination of a romantic naturalist, a cosmic wanderer looking for natural energy, or a pantheistic hedonist of new age puddling about in natural sexuality. In his daily life, the health pedagogue sees a poor substitute of this man in the form of an obscene nudist or health-obsessive vitalist.

\section{Health ideology after the Hindu fashion}

Postmodern ideology reduces the human condition to absurdity and health to substantial destruction. In pragmatic non-ideal societies, in which the ethos of family and patriotism is derided and culturally alien, religious sectarians come to the fore. They place themselves on the other pole of absurdity, right opposite the postmodern individualists (the absurdity in question is giving up social life but not physical life).

The findings of health historians allow us to see (but not really comprehend what is metaphysically incomprehensible) rebels against social profanity, who developed means of internal control of body cultivation (not to be confused with gymnastics in the European sense) in order to "become separated" from the world of family and society (Eliade, 1997, pp. 21-22). This pattern of physical culture, unknown to the West, was designed to detach hatha yoga practitioners from the worldly culture and direct them towards the divine (1997, p. 21). However, as long as mystics live - although they want nothing from the profane for themselves - they are burdened with worldly problems. They must move from the state of levitation to the state of gravitation. Even the guru who teaches others how to become separated from the physical world must, at least for a while, enter the mentality of the profane to manage conflicts and interests (Copleston, 1986). Such a mystic is like a certain guru in the German part of Europe who materializes in his stable luxurious Mercedeses and then receives contributions from sales of the matter of his assets. Those who make these contributions are his gullible Polish followers convinced of the total worthlessness of matter $^{4}$.

Certainly, a yoga practitioner may take different forms such as: magician, fakir, ascetic, mystic, wizard, or cannibal. Regardless, however, of any misidentifications of these forms by "inexperienced minds," in Eliade's view:

"To the Indian mind, 'common' human condition equals captivity, ignorance, and suffering; freedom, knowledge, and happiness remain unattainable until this 'commonness' is eliminated" (Eliade, 1997, p. 305).

Thus, for the yoga practitioner, the removal of human condition ontologically determines the choice of the one and only way of being. Unfortunately, the same metaphysical premise also serves as a means of justification of orgiastic or cannibalistic practices of the "dregs" of society (Eliade, 1997, p. 306).

The health pedagogue reminds us that the problematicity of the European rebel against the worldly life is contained in the question: Must man persist in his inborn natural condition? If the answer is NO then one arrives at a metaphysical contradiction by believing that non-existence is better than existence. Therefore, a problematic man is nothing but a self-destructive man. Once he has experienced the atmosphere of uncertainty in his historical time, [...] "he will know no peace, but wage a war against existence" (Patocka, 1998, p. 23). At best, he would make up a culture of existential nihilism for himself (life with no aim, sense or value); at worst, a culture of "denial of all that is human." He abstains from procreation, renounces sexuality, remains reluctant towards cosmic materiality, and elevates anti-somatism to the rank of norm of "denial of human condition." He therefore acts contrarily to the man of the West who is more mature in his self-comprehension of "life" destiny, remains within a community enhanced with moral virtues, and for whom the patterns of physical culture serve as means of communication with a higher worldliness of human condition, and even - despite human mortality - with the grace of eternal salvation.

\footnotetext{
${ }^{4}$ Details of the case are not revealed with respect to the interests of the indoctrinated individual.
} 
The mad Hindu contempt for social life astonish respectable Western conservatives as well as on victims of the postmodern failure of individualist selfishness who crave an existential sense. The value of the body yields numerous advantages; however, neither authoritarian statesmen, ideologues of stateless liberal democracies, or spiritual leaders of religious sects have managed to develop patterns of physical cultivation (heath culture systems) that would be useful to the man of community attaining perfection in human person. The notion of the human condition within a social community is synonymous with captivity in the Hindu mind. In Western philosophical thought, based on personalist humanism of social ontology, it is self-exlusion from community which is the metaphysical principle of human attainment of personal dignity. It was the Western sisters of mercy working among the Indian community of contempt for suffering who showed the superiority of a person achieving sanctity through love over a self-creating thaumaturge "feeding on remnants of his body" in an illusion of divinity - a mage healthy in the body and imaginarily invalid in the soul.

The health pedagogue only repeats after the meta-physicist that a person exists, through acts, for moral perfection, and that a person makes the value of the body - also attainable through acts - the supreme one (being its aim and sense). A person also favors the body - recognized as sacrum - as the temple of the person's spirit.

\section{Conclusions}

1. Public health policies arouse suspicion when a humanistically (personalistically) oriented pedagogue questions their axiological reasons; when he supposes that biopower - knowing that a human is an individual, personal, and substantial being (through its corporeality, physicality, health, and livelihood) publicizes and nationalizes a person's fitness with a cold, political calculation. This is the object at issue: the discourse of public health, which is essentially a dispute about the superiority of a social organization and, indirectly, about the status of the biopower that upholds and controls a system ideologized by the partisan good.

2. In this discourse, public health appears to be the subject of a public dispute, in which the health pedagogue speaks up for the health dignity of a person (student), indicates the direction of emancipation and exposes the vileness of the biopower apparatus ${ }^{5}$.

3. The health pedagogue's approach to the ideologues of postcolonial power is expository and accusatory. In particular, it concerns their occupational practices aimed at the commercialization of physicality and mockery of health. A customer can be first overfed, then slimmed, and then clad in dirty grunge clothes. Intentional filth is designed for the global market, which de-socializes and humiliates personal dignity. The ideologues of the power that controls physicality and degrades health encourage hedonistic partying and manipulate the lifestyle of their customers. The ecumene of the global market brings obesity into human lives accompanied by materialization that devolves the human being (without a soul and without love).

4. The ideological usurpers of power over the body, health, and lives of individuals have already been mentioned. A society which is totally controlled by the state is not the only reality individuals face and enter. This society cannot be chosen by individuals as they were born in it and it is their place, whether it be "an empire of evil," "civilization of death," or "inhuman land." There are parallel worlds to which individuals simultaneously belong, in which they can voluntarily, unaware of their personal, physical, and health-related objectification, seek self-fulfillment.

\footnotetext{
${ }^{5}$ The defense of students' rights to health dignity and criticism of the authoritarian power can be found in M. Demel's Szkice krytyczne o kulturze fizycznej (Critical Essays on Physical Culture), Warszawa 1973, SiT. A. Pawłucki criticizes the biopower of the liberal-democratic state as well as the implicit power of the postmodern control of the student's body in Nauczyciel wobec wartości zdrowia - studium krytyczne (Teacher and the Value of Health: A critical study), Gdańsk 1997, AWF.
} 
5. In defiance of those liberal or market-oriented ideologues of physicality, who commonly ignore the ideal of personal dignity, come learned axiologists. They situate themselves above various groups of particular interests, conflicting social forces and incessant struggle between conservatives and modernists. They establish intellectually the proper social order and regard the universal good as the foundation of health culture. They also indicate patterns of body cultivation and assign to them the humanistic meaning by deducing norms from the fundamental metaphysical principles. For example, they derive the obligation of enhancing health and recreational fitness by each social individual and working person from the responsibility of participation in the civilization of love (Pawłucki, 2007, p. 21; Pawłucki, 2009).

Public health is an instructive subject of public discourse with the pedagogue, with its balanced chances of defense of personal moral dignity, organization of society as a community for human persons, and state power affirming the common good for the person. The health pedagogue - being a conservative is the ultimate reminder (albeit without executive powers) proclaiming that an educating society can only persist successfully, if its biopower does not lose control in the struggle against the ideologues of neoliberal forces hostile to the solidarity-based and welfare state.

\section{REFERENCES}

Copleston, F. (1986). Philosophies and Cultures. Warszawa: PAX.

Eliade, M. (1997). Joga.Nieśmiertelność i wolność /Le Yoga. Immortalite et Liberte/. Warszawa: PWN.

Krąpiec, M.A. (2005). Ja - Człowiek /I, Human/. Lublin: KUL.

Legutko, P. (2012). Hospicjum, czyli biznes z o o /Hospice, Inc./, Gość Niedzielny, no. 10, 62-63.

Luhmann, N. (2007). Społeczne systemy. Zarys teorii ogólnej/Social Systems. Outline of General Theory/. Kraków: Nomos.

Nowak, W.A. (2011). Podmiot, systemy, nowoczesność /Subject, Systems, Modernity/, Poznań: UAM.

Patočka, J. (1998). Eseje heretyckie z historii filozofii /Heretical Essays in the Philosophy of History/. Warszawa: Aletheia.

Pawłucki, A. (2007). Osoba w pedagogice ciała /Person in pedagogy of the body value/. Olsztyn: OSW.

Pawłucki, A. (2009). Bliżej pedagogiki zdrowia/Closer to health pedagogy/. Wychowanie Fizyczne i Zdrowotne, no. 2 and 3, 4-12.

Straus, E.W., Straus, A. (2009). 100 największych osiągnięć medycyny /100 Greatest Medical Achievements/. Warszawa: Świat Książki.

Szacki, J. (2008). Przedmowa do wydania polskiego /Preface to the Polish edition/. In M.C. Nussbaum, Cultivating Humanity: A Classical Defense of Reform in Liberal Education. Wrocław: DSW, I-XIII.

Tischner, J. (2000). Miłość nas rozumie /Love Understand Us/. Kraków: Znak.

Szubert-Zarzeczny, U. (2001). Relacja ekonomia - polityka w nowożytnej myśli ekonomicznej /The relationship between economy and politics: politics in modern economic thought/. Wrocław: Wydawnictwo ARBORETUM.

Znaniecki, F. (1973). Socjologia wychowania/Sociology of Education/. Warszawa: PWN, vol. II, p. 23.

\section{AUTHOR'S ADDRESS: $\quad$ Andrzej Pawłucki}

Department of the Pedagogy of Physical Culture

Chair of the Pedagogy of Health

University College of Physical Education in Wrocław

ul. Witelona 25

51-617 Wrocław

Poland

Email: asp48@wp.pl 